\title{
Cave Temperature and Management Implications in Lehman Caves, Great Basin National Park, USA
}

\author{
Stanka Šebela ${ }^{1} \cdot$ Gretchen Baker $^{2} \cdot$ Barbara Luke $^{3}$ \\ Received: 19 December 2018 / Accepted: 30 April 2019 / Published online: 15 May 2019 \\ (C) The Author(s) 2019
}

\begin{abstract}
Cave air temperature was measured at six locations in Lehman Caves (USA) for one year at hourly intervals. Lehman is a show cave in a national park, treasured for its geological and biological resources. The two monitoring locations that are off of the tour route and, also, relatively distant from the cave's entrances displayed nearly constant air temperature during the year. The other four sites, along the tour route, show daily temperature variation as well as annual fluctuation. After visitation levels decreased in the autumn, cave temperatures lagged but eventually reached an equilibrium which demonstrates recovery in the quiet winter. The mean annual air temperature inside the Lehman Caves is significantly higher than outside $\left(1.9^{\circ} \mathrm{C} ; 20 \%\right)$ which points to an anthropogenic impact. A first-order analysis indicates that anthropogenic energy consumption in the Lehman Caves-which contributes to temperature rise - is about evenly divided between lighting and human presence. The study demonstrates that cave lighting and visitation levels have important implications for responsible management of this geoheritage site.
\end{abstract}

Keywords Cave climate $\cdot$ Cave management $\cdot$ Great Basin National Park $\cdot$ Lehman Caves $\cdot$ Nevada $\cdot$ USA

\section{Introduction}

In the United States, the National Park Service manages 59 national parks. Only one of these is unique to the State of Nevada. This is the Great Basin National Park (GBNP), which extends over 31,230 ha in the high desert and receives only $339 \mathrm{~mm}$ precipitation per year. The park is known for 3982-mhigh Wheeler Peak, for groves of bristlecone pine - the oldest known non-clonal organisms, and for the highly decorated Lehman Caves. Our study focuses on impacts to cave

Stanka Šebela

sebela@zrc-sazu.si

Gretchen Baker

gretchen_baker@nps.gov

Barbara Luke

barbara.luke@unlv.edu

1 Karst Research Institute, ZRC SAZU, Titov trg 2, 6230 Postojna, Slovenia

2 Great Basin National Park, 100 Great Basin National Park, Baker, NV 89311, USA

3 University of Nevada, Las Vegas, 4505 S. Maryland Pkwy., Las Vegas, NV 89154-4015, USA environment related to tourist use of the Lehman Caves and suggests management implications for sustainable use of the cave, a treasured geoheritage site in a national park.

About $18 \%$ of the area of the United States is underlain by soluble rocks having karst or the potential for development of karst features (Weary and Doctor 2014). The most visited cave in the United States is the Mammoth Cave System with 470,000 visitors in 2016 (529,000 recreational visitors to the Mammoth Cave National Park as a whole) (https://irma.nps. gov/Stats/, 2017). In the same year, GBNP, one of the least visited of the national parks, had 145,000 visitors (https:// irma.nps.gov/Stats/, 2017), of which 33,000 visited the Lehman Caves.

It is well-known that visitation can degrade the cave environment by introducing dust, lint, and lampenflora and by raising temperature (Cigna and Forti 2013). The environmental monitoring of a show cave ideally starts in the preoperational phase, to document its undisturbed status (Cigna and Burri 2010), and continues as an ongoing aspect of show cave operation.

Show caves are especially suitable for scientific studies because they have established infrastructure - trails to access distant parts of the cave, electricity, and sometimes even cabling to allow real-time data transfer for scientific and management issues. Some show caves have been incorporated into 
UNESCO "Geoparks" (Cigna and Forti 2013). The Geopark concept demonstrates how the area surrounding the cave must also be studied and protected (Ravbar and Šebela 2015; Auler 2016).

The purpose of our project was to record and analyze yearround air temperature in the Lehman Caves in order to understand the impacts of both tourism and the external climate on the cave climate. This study was undertaken because systematic micro-climatic monitoring in the Lehman Caves has not yet been fully conducted. Similar research has been developed on Slovene caves in a Classical Karst area, notably the Postojna and Predjama Caves, since 2009 (Šebela and Turk 2011, 2014; Šebela et al. 2015) and in other show caves worldwide (e.g., Veni 1999; Lario and Soler 2010; Cigna 2011; Jiménez-Sánchez et al. 2011; Santos Lobo 2015).

In the example of Lehman Caves, micro-climatic monitoring alone was not sufficient for cave management purposes. Data on cave visitation and outside cave climate was added to propose suitable management implications. Besides numerous environmental studies in show caves, cave tourism studies have been performed in other countries, including Korea (Kim et al. 2008), Turkey (Akca et al. 2016), Malaysia (Rindam 2014), New Zealand (Pavlovich 2003, 2014), Brazil (Santos Lobo et al. 2013), Spain (Lario and Soler 2010; Fernandez-Cortes et al. 2011), United States (van Beynen and Townsend 2005), and Slovenia (Šebela et al. 2015). An early study on effects of cave tourism on the climate for the Lehman Caves was presented by Stark in 1969. The passing of 50 years calls for a fresh look at the Lehman Caves' microclimate.

\section{Site Description}

Of 144 show caves in the United States (http:// goodearthgraphics.com/showcave/menu.html, 2016), the Lehman Caves are unique because they host an abundance of shields - $\mathrm{a}$ form of speleothem that has been observed in only a few caves worldwide, extensive evidence of condensation corrosion (dissolution of bedrock and speleothems due to seasonally high carbon dioxide levels), and rich subterranean fauna, including numerous endemic species (e.g., pseudoscorpions) (Fig. 1, Fig. 2). The cave is situated $500 \mathrm{~km}$ north from Las Vegas, Nevada (Fig. 1) and at higher elevation. A major tourist destination, Las Vegas received 42 million visitors in 2017 (LVCVA, Las Vegas Year-To-Date Executive Summary 2017). For tourists who would like to escape a hot and crowded Las Vegas summer, GBNP and the Lehman Caves present an ideal opportunity.

Of more than 580 documented caves in Nevada (Gilleland 2016), the Lehman Caves are the longest at about $3000 \mathrm{~m}$. They were discovered and first developed by rancher Absalom Lehman in 1885 (Schmidt 1987), and, at $2100 \mathrm{~m}$ elevation, they are one of the highest show caves in the United States. The Lehman Caves were included in the new Nevada National Forest in 1909 and declared a National Monument by President Warren G. Harding in 1922. In 1933, the National Park Service took over the Lehman Caves. The GBNP was established in 1986.

Later discoveries in the cave occurred in the 1940s and 1950s, but no new cave passages have been found since that time. From the time the National Park Service assumed management of the cave in 1933, park rangers have offered guided tours of the cave.

Surface water connected with winter precipitation percolates through the 30-60 m-thick cave ceiling and reaches the cave passages in one to twelve weeks. Measurements of cave micro-climate in the period 2009-2010 showed almost 100\% relative humidity and mean annual cave air temperature of $11^{\circ} \mathrm{C}$ (Steponaitis et al. 2015). The cave has only one known natural entrance. It is a vertical shaft less than $10 \mathrm{~m}$ deep and about $1.5 \mathrm{~m}$ wide. Entrance and exit tunnels, constructed in the vicinity of the natural entrance in 1939 and 1970, provide modern human access to the cave (Fig. 1).

The Lehman Caves and GBNP are part of the Basin and Range geologic province which extends across seven US states and Mexico (Collier 1990; Wernicke et al. 1988). The Lehman Caves are found in Middle-Cambrian age Pole Canyon Limestone. This rock layer has been slightly metamorphosed. The thickness of the metamorphosed limestone here is $450 \mathrm{~m}$. Within Pole Canyon Limestone, there are transitions from light to dark and thin to massive carbonates with minor quartzite and shale units, as well as dolomites (Drewes and Palmer 1957).

Being part of GBNP, the Lehman Caves and other caves in the park (GBNP has over 40 known caves in limestone and dolomite (National Park Service 2012)) are subject to biological, ecological, climatological, speleological, paleo-climate, and geomorphological research.

Intensive paleo-climate studies have taken place at the Lehman Caves. Data from two cave speleothems span the interval between 16.4 and $3.8 \mathrm{ka}$. Both $\mathrm{Mg} / \mathrm{Ca}$ and $\delta^{13} \mathrm{C}$ indicated a wet period at the beginning of the record (12.7-8.2 ka) followed by pronounced drying after $8.2 \mathrm{ka}$ (Steponaitis et al. 2015). A separate record of speleothem stable isotope $\left(\delta^{18} \mathrm{O}\right.$, $\left.\delta^{13} \mathrm{C}\right)$ and trace element $(\mathrm{Mg} / \mathrm{Ca}, \mathrm{Sr} / \mathrm{Ca})$ variations from the Lehman Caves covered the much earlier interval 139-128 ka (Cross et al. 2015).

Climate models indicate increasing temperatures and uncertain change in precipitation for the Great Basin region. Subalpine lakes at GBNP and their biota have persisted through other warm and dry periods; this is a positive message to share with visitors (Reinemann et al. 2011 and 2014).

Tang and Arnone (2013) analyzed trends and temperature extremes in surface air temperature in the Great Basin during 1901-2010. Annual average daily 

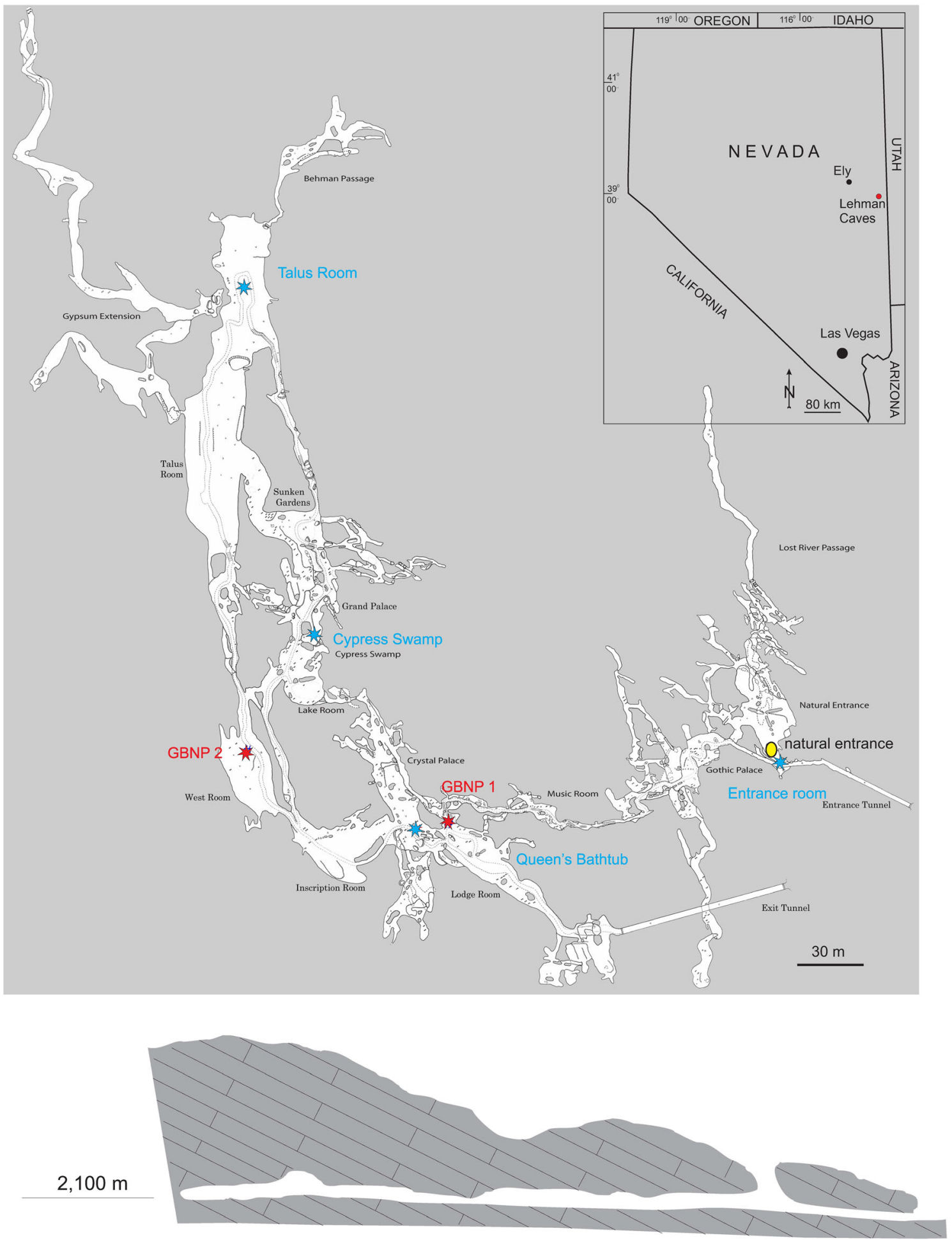

West Room

natural entrance

Fig. 1 Schematic map of Lehman Caves and profile showing locations of air temperature monitoring sites. Only the West Room and Talus Room sites are off the tour route. Monitoring sites GBNP 1 and GBNP 2 were placed in the cave expressly for this study. North is to the top of the image

minimum temperature increased significantly $(0.9 \pm$ $0.2{ }^{\circ} \mathrm{C}$ ) during the study period with daily maximum temperature increasing only slightly. Increase of daily minimum temperature was faster in winter. Annual average daily mean temperature in the Great Basin increased by $1.0{ }^{\circ} \mathrm{C}$ during the 110 -year period. 


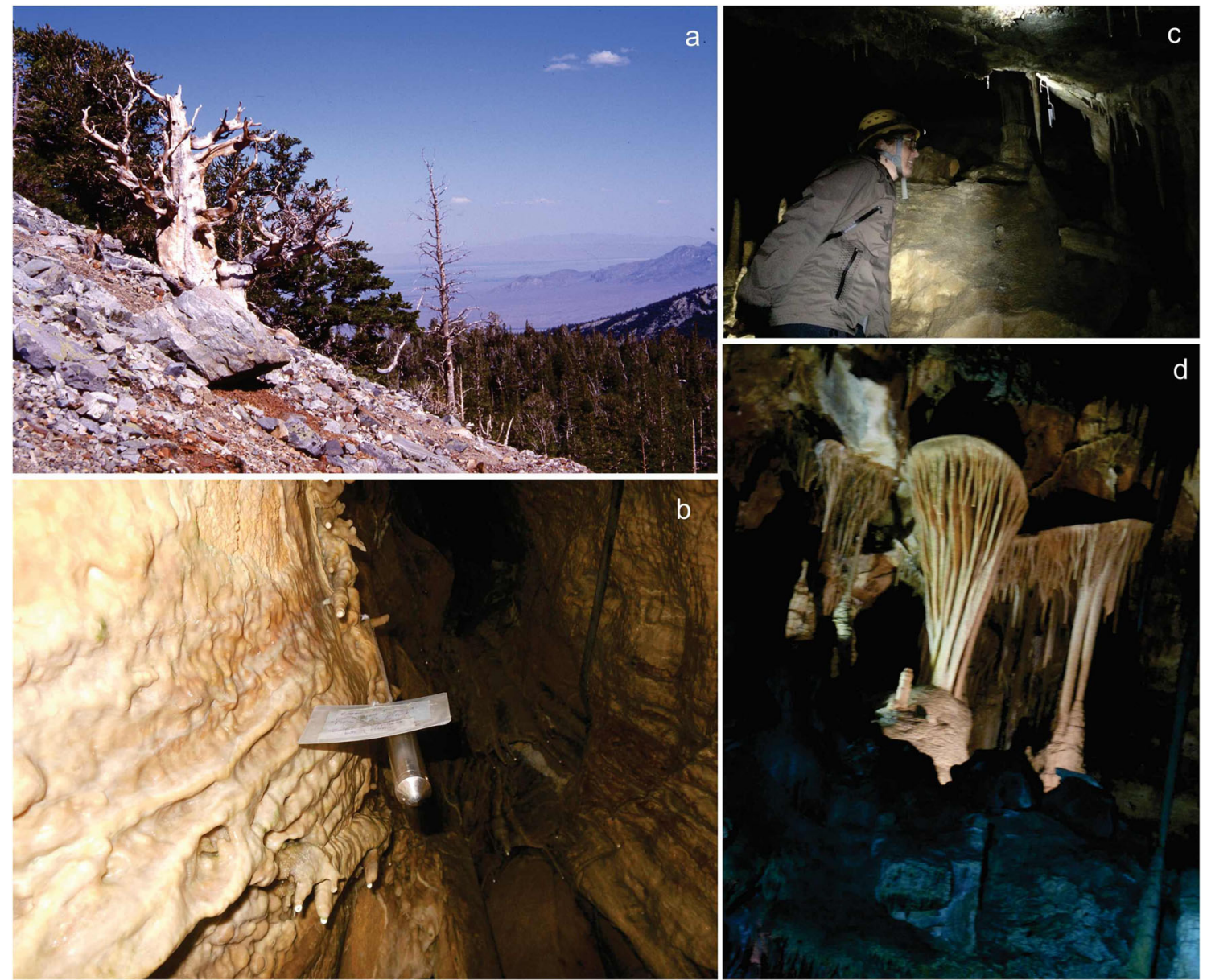

Fig. 2 a Rugged high desert with bristlecone pine in the Great Basin National Park; b instrument GBNP 1 for air temperature measurements, on the main tour route, view from below, instrument is $10 \mathrm{~cm}$ long; $\mathbf{c}$ instrument GBNP 2 for air temperature measurements near the ceiling of the West Room; $\mathbf{d}$ shield formations in Lehman Caves
These findings suggest that continuation of the overall warming trend will lead to markedly warmer conditions in upcoming decades. Among other things, increased temperatures are expected to extend fire seasons and increase the number of fires (McKenzie et al. 2004).

Ten new species of cave organisms have been found in GBNP caves in the last decade. Five new species of scuttle fly were reported (Disney et al. 2011). A Sciarid fly was also found (Vilkamaa et al. 2011). Two species of cave millipedes (Shear 2007; Shear et al. 2009) and a globular springtail (Zeppelini et al. 2009) have also been found. Stygobromus albapinus, a new stygobiotic amphipod crustacean species in the family Crangonyctidae, is described from two pools in GBNP's model cave (Taylor and Holsinger 2011). Because the use of caves by surface wildlife is a major nutrient source for cave organisms, digital infrared remote camera traps have been placed at entrances of twelve GBNP caves to assess wildlife use (Baker 2015).

\section{Methods}

To collect hourly data of cave air temperature, two Van Essen model 3001 data loggers were placed in the cave on 6 August 2015. The first location, GBNP 1, was near the tour route. The second location, GBNP 2, was off the tour route in the West Room, about $50 \mathrm{~m}$ below ground surface (Figs. 1 and 2). This site is along a route that was closed in 1981 due to safety concerns and is visited only rarely by staff and scientists. Accuracy of the measurements is $\pm 0.01{ }^{\circ} \mathrm{C}$. Battery life of the dataloggers is nominally years.

Four additional air temperature monitoring sites-Entrance Room, Queen's Bathtub, Cypress Swamp, Talus Room (Fig. 1) - had already been established under the management of GBNP. The instruments are Onset HOBO Tidbit v2 Temp Loggers, programmed to record hourly. Instrument accuracy is $+0.21^{\circ} \mathrm{C}$. Our intention was to compare hourly temperature data at these six cave locations over a one-year period against visitation and outside air temperature. 
GBNP and the Lehman Caves' visitation statistics (annual counts for the period 1922-2017, monthly counts for 2014 2016) and cave lighting data were obtained from GBNP. Mean monthly outside-cave air temperature was obtained from http:/www.wrcc.dri.edu/cgi-bin/cliMAIN.pl?nv4514. The meteorological station is located at the Lehman Caves Visitor Center, which is within $100 \mathrm{~m}$ of the cave entrance.

\section{Results and Discussion}

\section{Cave Meteorology}

The cave air temperature hourly dataset for the six locations (Entrance Room, Queen's Bathtub, Cypress Swamp, Talus Room, GBNP 1, and GBNP 2) was compared with outside mean monthly air temperature values (Fig. 3).

We checked the instruments during a visit to the Lehman Caves on 5-7 July 2016. GBNP 1 (Fig. 2) was recording normally, but GBNP 2 had stopped recording; it was removed from the cave at that time. This sensor yielded hourly temperature data for the 11-month period from 7 August 2015 to 4 July 2016. The instrument GBNP 1 was left in place until 28 September 2016 and thus obtained slightly more than one full annual cycle of data.

Fig. 3 Top, Hourly cave air temperature data $\left({ }^{\circ} \mathrm{C}\right)$ at six locations in Lehman Caves (refer to map in Fig. 1) from July 2015 to August 2016. Bottom, Mean monthly outside temperature (blue diamonds, left axis) and monthly visitation (green squares, right axis) inside Lehman Caves for July 2015 to July 2016.

Vertical bar indicates temperature range in top graph
The entrance room monitoring station shows air temperature ranging from 8 to $12.1^{\circ} \mathrm{C}$ over the period June 2015 to February 2016, but, due to instrument malfunction, we do not know the annual range. The span of more than $4{ }^{\circ} \mathrm{C}$ must be attributed to the strong impact of outside air on this site due to its proximity to the natural entrance.

The GBNP 1 site is on the tour route about $200 \mathrm{~m}$ from the natural cave entrance. Air temperature ranged from 10.7 to $11.6{ }^{\circ} \mathrm{C}$ for the period 7 August 2015 to 7 August 2016 (Table 1; Fig. 3). Variations followed a seasonal pattern: a marked drop in the winter and rise in the summer; a muted version of the pattern observed at the entrance room monitoring site (Fig. 3). At the GBNP 1 site, the annual temperature range is $0.9^{\circ} \mathrm{C}$ (Table 1) and daily fluctuations are $0.2^{\circ} \mathrm{C}$ in the summer and $\leq 0.1^{\circ} \mathrm{C}$ in the winter, when cave visitation is quite low. The mean annual air temperature is $11.2{ }^{\circ} \mathrm{C}(7$ August 2015 to 7 August 2016). The Queen's Bathtub site shows similar behavior throughout the year (Fig. 3). These two measurement sites are only about $30 \mathrm{~m}$ apart (Fig. 1).

At the GBNP 2 site, which is off the tour route in the West Room and about $340 \mathrm{~m}$ from the natural entrance, the air temperature held nearly constant at around $11.1{ }^{\circ} \mathrm{C}$ (ranging from 11.0 to $11.2{ }^{\circ} \mathrm{C}$ for the period 7 August 2015 to 6 July 2016). Only very slight seasonal variation is observed. Due to instrument failure, it was not possible to calculate statistical year-long values.
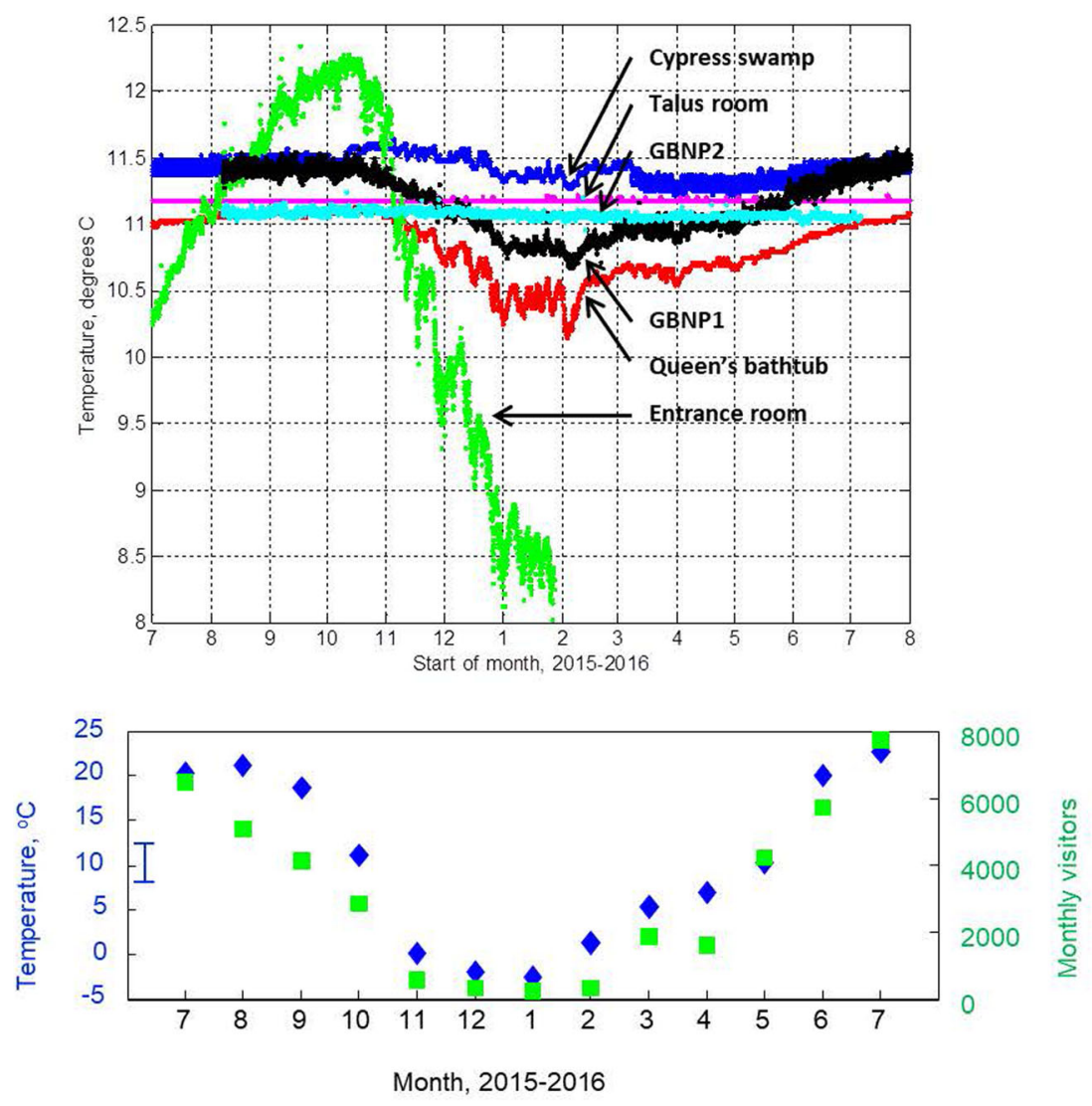
Table 1 Summary statistics for year-long air temperature data in ${ }^{\circ} \mathrm{C}$, from hourly data for period 1 July 2015 to 1 July 2016 for Cypress Swamp, Queen's

Bathtub, and Talus Room; period 7 August 2015 to 7 August 2016 for GBNP 1. Mean monthly data for period 1 July 2015 to 1 July 2016 for GBNP outside

\begin{tabular}{cccccc}
\hline & Cypress Swamp & Queen's Bathtub & Talus Room & GBNP 1 & GBNP outside \\
\hline Mean & 11.4 & 10.8 & 11.2 & 11.2 & 9.2 \\
Minimum & 11.2 & 10.1 & 11.2 & 10.7 & -2.6 \\
Maximum & 11.6 & 11.1 & 11.2 & 11.7 & 21.2 \\
Range & 0.4 & 1 & 0.04 & 1 & 23.8 \\
\hline
\end{tabular}

The Talus Room site, about $540 \mathrm{~m}$ from the natural entrance and well off the tour route, indicated air temperature of $11.2{ }^{\circ} \mathrm{C}$ for the period 1 July 2015 to 31 July 2016 (Fig. 3). Of the six sites monitored, this one showed the least temperature variation, both seasonally and daily.

At the Cypress Swamp site, about $370 \mathrm{~m}$ from the natural entrance, the air temperature ranged from 11.2 to $11.6^{\circ} \mathrm{C}$ for the period 1 July 2015 to 31 July 2016 (Fig. 3). This site is near the turnaround point of the tour route (farthest from the entrance). Even though it is at a similar distance from the entrance as GBNP 2, the temperature fluctuations, both daily and annually, were much higher.

Comparing data from the different sites (Fig. 3), we see that the locations Talus Room and GBNP 2 (West Room), which are both off the tour route and, also, distant from the cave entrance (Fig. 1), show nearly constant temperatures throughout the year. The temperature difference between the two sites is about $0.1^{\circ} \mathrm{C}$. It appears that these two sites are little affected by outside air currents entering the cave, or even in-cave air currents.

At the GBNP 1 and Queen's Bathtub sites, the wintertime drop of air temperature below the flat values at the GBNP 2 and Talus Room sites shows that outside air may have an impact on cave air at those locations. During winter, the ventilation regime of outside air coming into the cave from the natural entrance decreases cave air temperature at GBNP 1 and Queen's Bathtub sites, and also somewhat at the Cypress Swamp site, but it has almost no impact on cave air in the GBNP 2 and Talus Room sites. The maximum winter air temperature drop at Queen's Bathtub is about $1{ }^{\circ} \mathrm{C}$ lower than that in the Talus Room. In summer, air temperature at the Queen's Bathtub site stabilizes around the same values as the GBNP 2 site, while the summer values at the GBNP 1 site are about $0.3{ }^{\circ} \mathrm{C}$ higher than those at the GBNP 2 and Queen's Bathtub sites, similar to those measured at the Cypress Swamp.

At the Cypress Swamp site, the pattern is similar but muted with respect to the GBNP 1 and Queen's Bathtub sites. However, there are two brief periods of temperature riseabout $0.25{ }^{\circ} \mathrm{C}$ from the end of October to mid-December 2015 and $<0.2^{\circ} \mathrm{C}$ in February-March 2016 (Fig. 3). These increases are puzzling. The monitoring site is in a lower passage, which would generally be expected to be a cold air sink.
However, there is an electrical transformer only $1 \mathrm{~m}$ away, whose heat might have influenced the air temperature at the sensor if the lights in that area were inadvertently left on - the lights are normally turned off every night using a master switch. The similarity of summer air temperature values at the Cypress Swamp and GBNP 1 shows that those two locations, which share the highest summer air temperatures, demonstrate the flow path of warm air during summer. Daily oscillations at the two locations, about $0.2^{\circ} \mathrm{C}$, are typical for caves with daily tourist visits (Šebela and Turk 2011). These daily oscillations are much higher than those observed at the sites off the tour route, GPNP and Talus Room, and lower than those at the entrance room (Fig. 3).

Higher daily oscillations in cave air temperature and higher overall air temperatures at GBNP 1, Queen's Bathtub, and Cypress Swamp sites during the summer period may show visitors' impact. In some caves, for example, the Mammoth Cave, airflow is said to be driven by the chimney effect, meaning that temperature differentials between air inside the cave and air outside the cave influence airflow patterns throughout the cave (Jernigan 2001). In the Lehman Caves, the chimney effect is most visible with winter ventilation. In winter, when outside air temperature is less than cave air temperature $\left(T_{\text {out }}\right.$ $<T_{\text {cave }}$ ), we see air temperature decrease at the Entrance Room, GBNP 1, and Queen's Bathtub monitoring sites (Fig. $3)$. During summer, when $T_{\text {out }}>T_{\text {cave }}$, the cave air is heated by entry of outside warm air into the cave, by the increased presence of humans, and by the cave lights. These seasonal fluctuations do not affect the entire cave uniformly: they are muted at the Cypress Swamp (near the tour route turnaround) and they are barely seen or undetected off the tour route in the Talus Room and West Room (GBNP 2 site).

The air temperature monitoring locations at the Lehman Caves that are on the tour route show characteristics of a socalled thermal cave. According to Pflitsch et al. (2010), the air flow within thermal caves has a strong seasonal characteristic, with clear difference between summer and winter. Barometric caves, in contrast, show only small differences in air temperature between summer and winter-as is the case at the Lehman Caves for Talus and West Rooms.

There is evidence that both thermal and barometric effects exist inside a single-cave system and even over short distances (Boes et al. 1997). To find out whether the Talus and West 
Rooms show barometric-cave characteristics, air pressure monitoring would be needed.

In the past, Stark (1969) studied five different representative light positions at the Lehman Caves with lights on and off to better understand the effect of microclimate on cave organisms. The author showed that one of the strong controlling factors was the drying power of the air caused by turning lights on and off in various reflecting positions.

In the same study, Stark (1969) measured air temperature over $8 \mathrm{~h}$ in November 1968 when lights were off. The mean air temperature was $10.8{ }^{\circ} \mathrm{C}$, with the range $10.1-11.4{ }^{\circ} \mathrm{C}$. This is overall about $0.6{ }^{\circ} \mathrm{C}(\sim 6 \%)$ lower than average temperatures measured in November 2015 on the tour route at station GBNP 1.

The highest cave-visitor counts correspond with highest cave air temperature values (Fig. 3). At Cypress Swamp and GBNP 1 locations, cave air temperature remains elevated even after visitation declines, as seen in August and September 2015. Furthermore, in May and June 2016, all stations on the tour route showed cave air temperatures rising in parallel with the increase of visitors (4229 visitors in May and 5723 visitors in June) and increase of outside air temperature. In 2015, the cave air temperature did not decrease until October. Note that in September 2015 the outside air temperature decreased, yet, inside the cave, air temperatures remained steady near the summertime high (Fig. 3). Cave visitation remained fairly strong in September. This is further evidence that cave visitation is influencing cave air temperature. Time lag in the decrease of cave air temperature with respect to outside air temperature is described in other caves (show and not show caves) too (Šebela and Turk 2011).

Annual air temperature values at the weather station near the Lehman Caves Visitor Center, which is less than $100 \mathrm{~m}$ from the cave entrance, for years 1951-2011 show a mean of $9{ }^{\circ} \mathrm{C}$ (Prudic et al. 2015). Mean year-long outside air temperature for the period 1 July 2015 to 1 July 2016 (http://www. wrcc.dri.edu/cgi-bin/cliMAIN.pl?nv4514) is $9.2^{\circ} \mathrm{C}$, which is $1.9^{\circ} \mathrm{C}(\sim 20 \%)$ lower than the year-long average cave air temperature at GBNP 1 (computed over a slightly different time period: 7 August 2015 to 7 August 2016). These data show that the Lehman Caves' annual air temperature values are higher than outside: $20 \%$ higher than the mean outside air temperature of $9.2^{\circ} \mathrm{C}$ from our study (2015-2016) and $24 \%$ higher than the $9{ }^{\circ} \mathrm{C}$ for the period 1951-2011 reported by Prudic et al. (2015). This difference demonstrates that the outside winter air, which enters the cave primarily through the natural entrance shaft (Fig. 1), decreases cave air temperature only incrementally. The remote cave monitoring sites - Talus Room and West Room (sensor GBNP 2)—also show considerably higher mean annual air temperature than that in the outside (Table 1). Two possibilities may account for this-(1) natural heat flux from the Earth's interior is warming the cave atmosphere and (2) the cave air is accumulating heat from visitors and lighting in the cave.

Natural heat flux from the Earth's interior (possibility number 1) is not likely for the Lehman Caves because there are no known hot or warm springs or other signs of active volcanism in the vicinity (radius $20 \mathrm{~km}$ ). Future measurements of cave rock temperature (on and off the tour routes) could help to determine the influence of geothermal flux on cave air temperature.

Our cave micro-climate results support the second possibility that anthropogenic factors are causing a rise in the Lehman Caves' air temperature. Probably the best proof for this is the Little Muddy Cave, which is not a show cave. It is located near the Lehman Caves $(0.5 \mathrm{~km}$ distant and about $100 \mathrm{~m}$ lower elevation). Its mean air temperature from November 2005 to November 2006 was $9.7^{\circ} \mathrm{C}$. This is $1.5{ }^{\circ} \mathrm{C}$ lower than the mean cave air temperature at the Lehman Caves (stations GBNP 1 and Talus Room) and is better harmonized with the outside air temperature of $9.2^{\circ} \mathrm{C}$ (Fig. 4). This information is additional evidence that cave air temperature at the Lehman Caves is elevated with respect to natural conditions - in other words, due to anthropogenic impact.

The Lehman Caves are the only show caves at GBNP. The nearest show caves with electric lights are the Timpanogos Caves near the American Fork, Utah, which are situated $290 \mathrm{~km}$ northeast from the Lehman Caves at an elevation of $2050 \mathrm{~m}, 500 \mathrm{~m}$ lower than Lehman. This show cave, which receives about 69,400 visitors in a 6-month season (http:// nckms.org/wp-content/uploads/2018/05/2005_Jaspervisitation.pdf, 2016), has temperatures considerably lower than those at Lehman, ranging from 7.2 to $8.8^{\circ} \mathrm{C}$. The two caves are too distant and with sufficiently different geomorphology and geology that simple comparison of cave air temperatures is not meaningful. Deeper studies would be needed to understand why air temperatures at the Timpanogos Caves are so much lower than those at Lehman Caves.

Cave environment influenced by heat emissions from visitors and lighting is described for other show caves, such as Kateřinská Cave (Moravian Karst, Czech Republic) (Středa et al. 2014), Nerja Cave (Malaga, Spain) (Carrasco et al. 2002), and Postojna Cave (Slovenia) (Šebela et al. 2015), where temperature elevations above ambient are similar to those at the Lehman Caves.

In the example of the Lehman Caves, we cannot exclude the fact that the cave is developed in marbles (metamorphosed limestone), which have excellent thermal conductivity and can absorb large amounts of heat, even more than limestone (Walker et al. 2014). Elevated cave air temperatures at the Lehman Caves can point to accumulated heat in the marble resulting from modernday tourism and, also, from previous years when the numbers of visitors were not limited as it is today. 


\section{Park and Cave Visitors}

By 2007, over one million people had walked through the Lehman Caves. Annual visitor numbers for the Lehman Caves and GBNP for the period 1922-2017 are presented in Fig. 5. These data were obtained from GBNP. It appears that prior to 1966 the numbers of cave visitors were not counted separately from the park visitors.

After the year 1988, when the Lehman Caves received its maximum of 50,780 visitors, the number of park visitors strongly increased (147,193 in 2015), but, by 2015 , the number of cave visits stabilized at around 33,000 per year (Fig. 5a). The reduction is due to the Park limiting tours and not to any decrease in demand. An online reservation system for cave tours started in 2016. There are generally 10-15 tours daily in summer, with no more than 20 people per tour. Cave tours fill nearly every day in summer.

Visitor numbers for the period October 2014 to September 2016 (Fig. 5b) show monthly distributions for the park and the cave. Over this two-year period, the park's visitation was highest in May (21,314 in 2015) and July (21,314 in 2015 and 22,599 in 2016). Visitation to the Lehman Caves was highest in July (6482 in 2015 and 7747 in 2016). Monthly visitation to the Caves declined drastically in winter, ranging from 220 to 560 .

The fundamental principles for development of a show cave are protection of the environment and safety of the visitors (Cigna 2011). According to the UIS Management Guidelines for Show Caves, the energy balance of a cave should not be modified beyond its natural variations (Cigna and Forti 2013). Electric wiring should be zoned to enable lighting only where visitors are located (Cigna and Forti 2013).

In the case of GBNP and the Lehman Caves, it is important to note the increase of park visitors compared with the number of cave visitors for the period 2000-2016 (Fig. 6). Although some visitors will not have access to the cave because tickets are not available, GBNP offers numerous activities besides the cave tour to diffuse the Park visitors.

\section{Management Implications}

For the Lehman Caves, there are four key issues related to the use of the cave for tourism, which are as follows: (1) limiting numbers of visitors and the extents of their visits, (2) cave micro-climate and biological monitoring, (3) lampenflora growth around cave lights, and (4) anthropogenic remains in the cave, most notably lint.

Visitor numbers (1) at the Lehman Caves are already limited due to environmental protection and staffing considerations. The effects of visitation on cave formation, especially growth of speleothems, have not been investigated and are worthy of study.
For in situ monitoring of visitor impacts on cave environment, permanent meteorological stations should be placed in the cave. It is necessary to monitor continuously at least the most sensitive cave parameters (2) in order to mitigate a situation as soon as problems appear. In addition to the usual parameters - air temperature, relative humidity, air pressure, water temperature, airflow in and out of the cave - radon and cave air $\mathrm{CO}_{2}$ concentrations have been shown to be important for micro-climatic monitoring (Fernandez-Cortes et al. 2011; Šebela et al. 2013; Bourges et al. 2014) and in some caves methane measurements are appropriate (Mattey et al. 2013; Webster et al. 2016).

Regarding micro-climatic and biological monitoring results at the Lehman Caves, carrying capacity and/or the environmental disturbance index must be determined (Santos Lobo 2015). Karst environments, unique from other environments, require their own disturbance indices. Increasingly, karst resources are being disturbed by numerous processes related to social, physical, and economic factors.

Working with the Tito Bustillo Cave, a karst cave in Northern Spain, which was designated a World Human Heritage Site in 2008, Jiménez-Sánchez et al. (2011) designed a method for evaluating the degree of conservation of the geomorphological heritage and human impact linked to the opening of the cave for tourism. Categories in their GISbased geomorphologic heritage cave map included natural heritage, cultural heritage, and geomorphologic impacts derived from tourist use (Jiménez-Sánchez et al. 2011).

Conservation of speleological heritage involves bioecological, geomorphological, and anthropogenic studies inside the caves (Mulec, 2014) and, also, of the external environments that surround them. Donato et al. (2014) established a Cave Conservation Index (CCI) for nine caves in Brazil, to identify areas that should be protected and caves that should be prioritized for conservation and restoration. Considering the Santana Cave (Brazil), Santos Lobo (2015) presented tourist-carrying capacity as a dynamic tool, not just to limit impact but also to improve visitor experience. Earlier, Middaugh (1977) had cautioned that carrying capacity analysis is not merely the calculation of a number but rather involves the definition of a problem, the formulation of objectives to solve that problem, and the implementation of proper management to solve the problem.

The majority of research on environmental impacts of tourism in China caves has been qualitative and descriptive in nature, with a lack of both case studies and theoretical development (Zhong et al. 2011).

Lampenflora growth at the Lehman Caves (3) is another consideration. Crews regularly enter the cave to clean and remove algae growths using spray bottles filled with a heavily (10\%) diluted bleach solution. Such treatments could potentially be applied more often. Additionally, hydrogen peroxide might be tested as an alternative cleansing agent. This was 
Fig. 4 Relations between air temperatures outside, in the show cave, and in a nearby wild cave in ${ }^{\circ} \mathrm{C}$. Vertical axis shows air temperature for the period 2015 2016 for mean monthly values (Talus Room (Lehman Caves), GBNP 1 (Lehman Caves), and outside air) and mean annual air temperature at Little Muddy Cave (2005-2006)

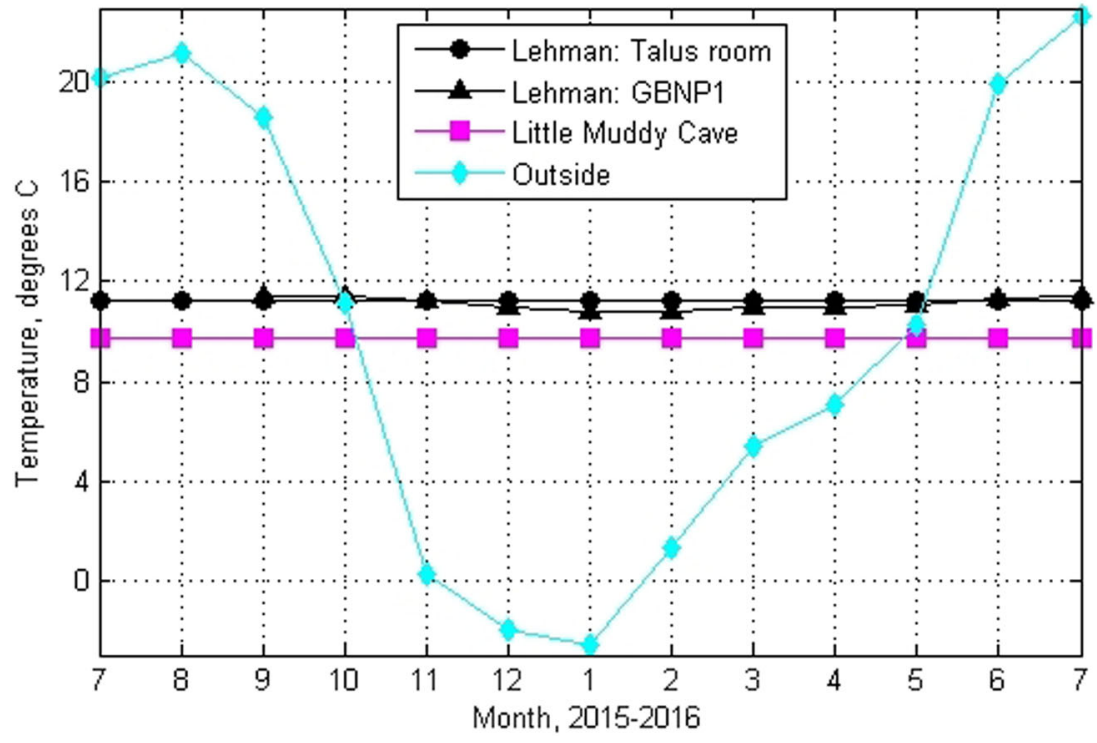

done in the Moravian Karst, Czech Republic, where the threshold hydrogen peroxide concentration for the destruction of lampenflora was found to be $15 \%$ by volume (Faimon et al. 2003).

The entrance and middle sections of the cave were lighted in 1941. The last section (Talus Room) was lighted in 1960 (Stark 1969). After the lights were emplaced, the slow colonization by plants (lampenflora) and microscopic animals from spores began. Plants living in the cave are dispersed by spores probably brought in by water and moved around on the feet of tourists and trogloxenes. In the period 1940 to 1969 , the largest plant to invade the cave and stay was a small fern (Cystopteris fragilis var. Fragilis) (Stark 1969).

In 2006, park staff replaced incandescent bulbs with lightemitting diodes (LEDs), which last an average of 50,000 h, are resistant to shock, operate at low temperatures, and consume 20 $25 \%$ the amount of electricity. Even with LED lights, algae continues to grow, but at slower rates (https://www.nps.gov/ grba/learn/nature/algae-reduction.htm, 2016). A lighting system for the cave that reduces algal growth is of course desirable.
Fig. 5 a GBNP and Lehman Caves annual visitor numbers for the period 1922 to 2017 , b GBNP visitors and Lehman Caves monthly visitors numbers for the two-year period October 2014 to September 2016
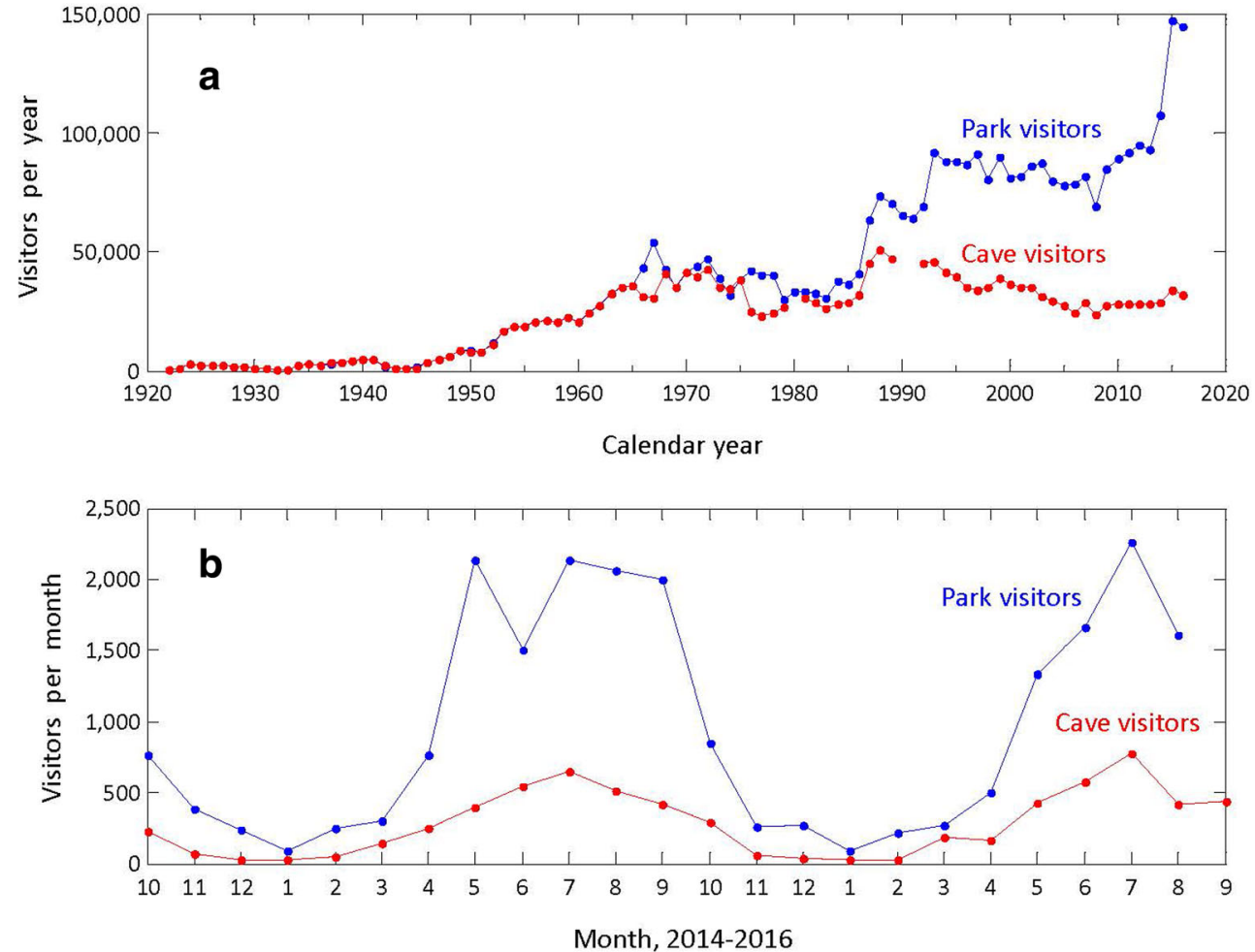

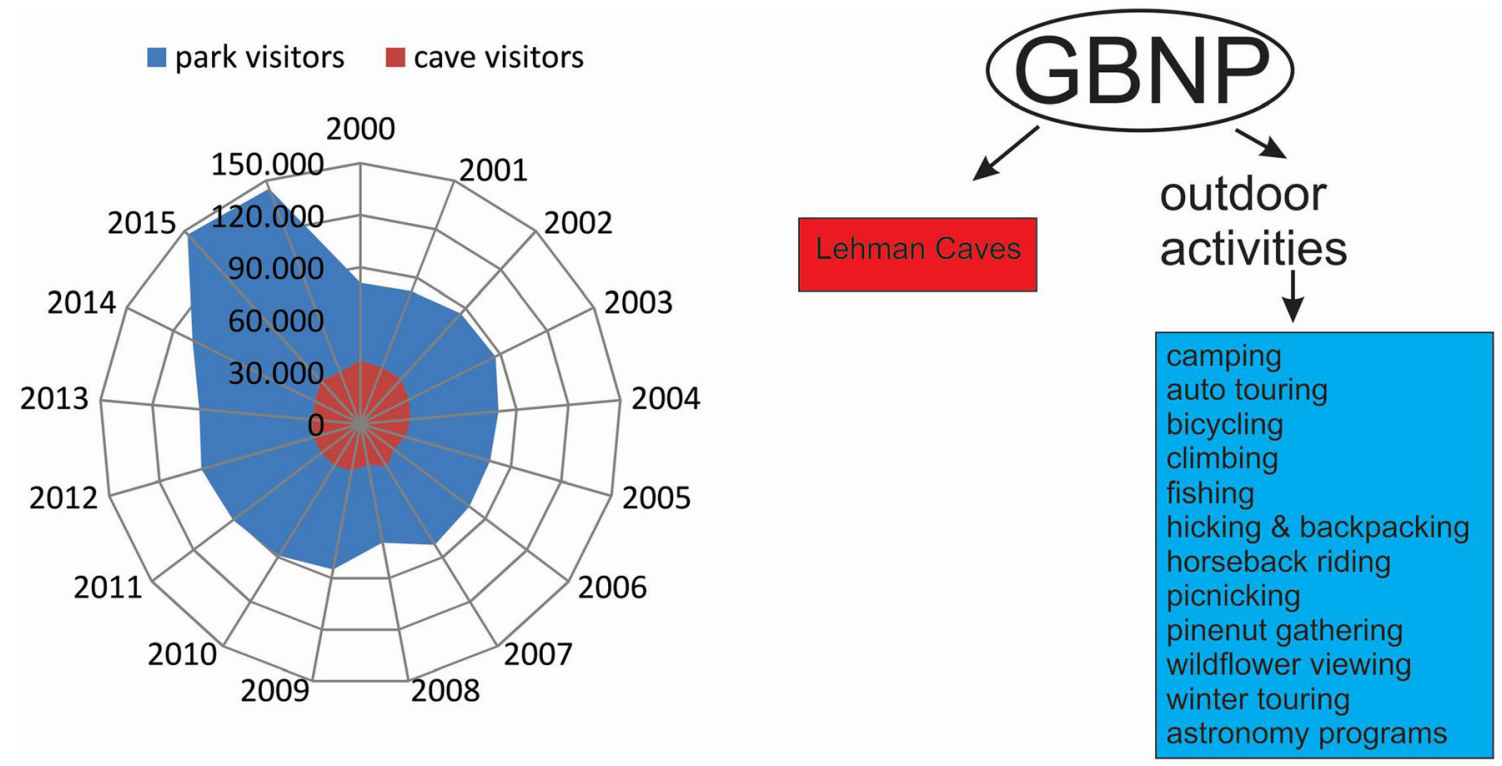

Fig. 6 Relation between numbers of cave and park visitors and GBNP tourism activities for the period 2000-2016

We explored the relative expenditure in the cave of energy from lighting and from human presence (Table 2). (While the rough calculation of energy expenditure presented here was fairly straightforward, determining relative contributions from the two energy sources to temperature rise in the cave would be much more involved.) Interestingly, at present, the energy expenditures in the Lehman Caves from the two sources are about equal. In round numbers, for lighting, 230 bulbs burning at a weighted average of 12 watts apiece for about $2500 \mathrm{~h}$ per year equates to 24 billion joules of energy consumption annually. While lights burn electricity, humans run on food, for which energy consumption is reported directly in joules. Assuming average daily energy consumption per person of 9.0 million joules, spread out evenly over $24 \mathrm{~h}$ day, 61,000 person-hours visitation per year equates to about 23 billion joules of energy consumed annually in the cave. We expect that much of the energy consumed by both systems is given off as heat, neither system being highly efficient. If the efficiencies of the two systems were equal, the ratio of heat introduced by lighting versus that introduced by people would be about 1:1. This sort of quick calculation might be helpful in guiding decisions about setting limits for visitation and/or planning for illumination.

The fourth issue (4) addresses traces of human presence in the Lehman Caves mainly in the form of lint, which covers speleothems and cave routes. Lint is introduced to the cave environment by the approximately 33,000 people who enter the cave each year. Lint is composed of fibers, hairs, skin cells, dust, and other foreign particles. This issue is being managed by volunteers, who twice a year spend cumulatively more than $300 \mathrm{~h}$ manually cleaning speleothems and cave walls along sections of the tour route. Pounds of lint and dust are removed annually, helping to restore the cave to a more natural state.
Some areas of the cave, particularly those with stronger air currents, have lint resettle on them quickly and so have to be cleaned annually. High ceiling areas in the Gothic Palace was the site of some of the most concentrated lint accumulations in the cave, indicating the presence of air currents that cause lint deposition 6-10 m off the ground (Thomas 2008). Dust and lint that collect in dark areas support fungi, and occasionally Protozoans (Stark 1969). One management option is to process visitors through a sort of vacuum pressure chamber at the cave entrance to collect loose particles, thereby reducing the amount transported into the cave. Other possibilities could involve enlisting visitors to voluntarily modify their behavior and dress. As lint is only reported in touristic caves, comparison with non-show caves cannot be made.

\section{Conclusions}

Year-long air temperature monitoring data in the Lehman Caves (Nevada, USA) was conducted to better understand cave micro-climate and impact of tourism and outside climate on the show cave. Hourly data of cave air temperature was collected at six sites in the period 7 August 2015 to 28 September 2016. Data from two monitoring sites installed as part of this project (GBNP 1 and GBNP 2) supplemented data from pre-existing monitoring sites (Entrance Room, Queen's Bathtub, Cypress Swamp, and Talus Room).

Results show that the two monitoring sites off the tour route (West Room (sensor GBNP 2) and Talus Room) display virtually constant air temperature year-round. Of the six monitoring sites, those two are the least visited, as well as being relatively far from the cave's natural entrance. Air temperatures at sites along the tour route show an annual cycle with 
Table 2 Energy consumption analysis

\begin{tabular}{llll}
\hline Energy source & $\begin{array}{l}\text { Unit hourly energy consumption } \\
\text { (joules) }\end{array}$ & $\begin{array}{l}\text { Hours over one year that energy is expended in } \\
\text { the cave }\end{array}$ & $\begin{array}{l}\text { Total energy consumption in the cave per year } \\
\text { (joules) }\end{array}$ \\
\hline $\begin{array}{l}\text { Human } \\
\text { visitation } \\
\text { Lighting }\end{array}$ & 374,991 per person $^{\mathrm{a}}$ & 61,249 person-hours & 23.0 billion \\
\hline
\end{tabular}

${ }^{\text {a }}$ Obtained by averaging daily energy intake for US men and women in 2013-2014 according to the National Center for Health Statistics (2017)

${ }^{\mathrm{b}}$ Lehman Caves visitation in one year, October 2015-September 2016

${ }^{\mathrm{c}}$ Average wattage for bulbs used in Lehman Caves is 11.615

${ }^{\mathrm{d}}$ Lehman Caves burns 230 bulbs underground for about $2525 \mathrm{~h}$ over the course of a year

highs in summer and lows in winter. The reduction of winter air temperatures at sites on the tour route and relatively close to the entrance, from 0.3 to $0.8^{\circ} \mathrm{C}$ below the roughly constant values at the West Room and Talus Room, demonstrates intrusion of colder outside air into some parts of the cave. The sites GBNP 1, Queen's Bathtub, and Entrance Room are close to the natural cave entrance; for this reason, they have a more marked annual temperature fluctuation than do the sites deeper in the cave.

Daily oscillations seen in summer at GBNP 1, Queen's Bathtub, and Cypress Swamp can be explained by the heat signatures of the human visitors and cave lighting. In winter, daily oscillations are lower due to less visitation-less body heat and also less lighting because of fewer tours.

Year-round monitoring showed that mean annual air temperature at the Lehman Caves is $1.9^{\circ} \mathrm{C}(20 \%)$ higher than outside the cave $\left(9.2^{\circ} \mathrm{C}\right)$. The Little Muddy Cave, which is not a show cave and is only $0.5 \mathrm{~km}$ distant from the Lehman Caves, showed $9.7^{\circ} \mathrm{C}$ as mean air temperature. This difference points to an anthropogenic impact on the Lehman Caves atmosphere, perhaps exacerbated by excessive visitation in previous years (especially in the period 1987-1994 with 360,000 visitors) but also due to the current visitation when a residual temperature shift remains. Even though cave visitors today represent only $22 \%$ of the visitors to GBNP, the already existing cave visitation limits (about 33,000 visitors per year) must be taken into account for future management implications and should not be exceeded.

Anthropomorphic temperature elevation in the cave comes from inefficiencies in converting energy. The major sources of heat are burning electricity to provide light and "body heat"-humans burning energy to sustain their lives underground as they move through the cave. A simple calculation for current conditions at the Lehman Caves showed a roughly even distribution of energy consumption in the cave between lighting and human presence. If the two systems were equally inefficient-we would argue this to be a reasonable first-order approximation of values that are difficult to pinpoint - their contributions to cave warming would also be equal. This simple calculation might prove useful in show cave management, for designing lighting and setting visitation limits.

Management recommendations for the Lehman Caves include the following:

- Continue limiting the number of people entering the cave.

- Turn off cave lights when not needed.

- Measure wind speed and direction, humidity, cave air pressure, and $\mathrm{CO}_{2}$ to inform future micro-climatic studies and ongoing monitoring. With comprehensive cave micro-climatic monitoring, it will become possible to better understand the natural climate at the Lehman Caves and the impacts of outside climate and tourism on the cave's micro-climate.

- Measure rock temperature to see if geothermal flux can be contributing to increased cave air temperatures.

- Offer virtual cave visits for Park visitors who cannot enter the cave due to limited opportunities.

Opportunities for additional study, such as anthropogenic impact on water flow and therefore the creation of speleothems at the Lehman Caves, remain unsolved.

Acknowledgements The study was done within the project Climatic monitoring in show caves: comparison of conditions from Slovene karst caves with karst areas of east-central Nevada, USA (GRBA-2015-SCI0015), Slovenia-USA bilateral projects (BI-US/15-16-054) Monitoring of active tectonic micro movements: comparison of conditions from Slovene karst caves with karst areas of Southern Nevada, USA, and (BI-US/1820-049) Cave meteorology as important tool for understanding natural and human impacts on caves and ARRS program Karst Research (P60119). The project at the Lehman Caves was proposed as cooperation between the Great Basin National Park (USA), UNLV (USA), and ZRC SAZU (Slovenia).

Open Access This article is distributed under the terms of the Creative Commons Attribution 4.0 International License (http:// creativecommons.org/licenses/by/4.0/), which permits unrestricted use, distribution, and reproduction in any medium, provided you give appropriate credit to the original author(s) and the source, provide a link to the Creative Commons license, and indicate if changes were made. 


\section{References}

Akca H, Sayili M, Cafri R (2016) Analysing expenditure of same-day visitors in cave tourism: the case of Turkey. Tour Econ 22(1):47-55. https://doi.org/10.5367/te.2014.0413

Auler AS (2016) Cave protection as a karst conservation tool in the environmentally sensitive Lagoa Santa Karst, Southeastern Brazil. Acta Carsologica 45:131-145

Baker GM (2015) Quantifying wildlife use of cave entrances using remote camera traps. J Cave Karst Stud 77:200-210. https://doi.org/ 10.4311/2015ES0101

Boes C, Ek C, Kies A, Massen F, Schintgen G, Sinner E, Waringo G (1997) The Maestroff Cave, a study on the geology and climate of Luxembourg's largest maze cave. Centre de Recherches Public Centre Universitaire, Luxembourg

Bourges F, Genthon P, Genty D, Lorblanchet M, Mauduit E, D'Hulst D (2014) Conservation of prehistoric caves and stability of their inner climate: lessons from Chauvet and other French caves. Sci Total Environ 493:79-91. https://doi.org/10.1016/j.scitotenv.2014.05.137

Carrasco F, Vadillo I, Liñán C, Andreo B, Durán JJ (2002) Control of environmental parameters for management and conservation of Nerja Cave (Malaga, Spain). Acta Carsologica 31:105-122. https://doi.org/10.3986/ac.v31i1.407

Cigna AA (2011) Show cave development with special references to active caves. Tourism and Karst Areas 4:7-16

Cigna AA, Burri E (2010) Development, management and economy of show caves. Int J Speleol 29:1-27

Cigna AA, Forti P (2013) Caves: the most important geotouristic feature in the world. Tourism and Karst Areas 6:9-26

Collier M (1990) An introduction to the geology of Death Valley. Death Valley National History Association, Death Valley

Cross M, McGee D, Broecker WS, Quade J, Shakun JD, Cheng H, Lu Y, Edwards RL (2015) Great Basin hydrology, paleoclimate, and connections with the north Atlantic: a speleothem stable isotope and trace element record from Lehman Caves, NV. Quat Sci Rev 127: 186-198. https://doi.org/10.1016/j.quascirev.2015.06.016

Disney RH, Taylor S, Slay ME, Krejca JK (2011) New species of scuttle flies (Diptera: Phoridae) recorded from caves in Nevada, USA. Subterranean Biology 9:73-84. https://doi.org/10.3897/subtbiol.9. 2511

Donato CR, de Souza Ribeiro A, de Sousa Souto L (2014) A conservation status index, as an auxiliary tool for management of cave environments. Int J Speleol 43:315-322. https://doi.org/10.5038/1827806X.43.3.8

Drewes H, Palmer AR (1957) Cambrian rocks of Southern Snake Range, Nevada. AAPG Bull 4:104-120

Faimon J, Stelcl J, Kubešova S, Zimák J (2003) Environmentally acceptable effect of hydrogen peroxide on cave "lamp-flora", calcite speleothems and limestones. Environ Pollut 122:417-422. https:// doi.org/10.1016/S0269-7491(02)00309-3

Fernandez-Cortes A, Cuezva S, Sanchez-Moral S, Cañaveras JC, Porca E, Jurado V, Martin-Sanchez PM, Saiz-Jimenez C (2011) Detection of human-induced environmental disturbances in a show cave. Environ Sci Pollut Res 18:1037-1045. https://doi.org/10.1007/ s11356-011-0513-5

Gilleland T (2016) The caves of Nevada. In: Hoke R (ed) 2016 NSS convention guidebook. National Speleological Society, Huntsville, Alabama, p 94

http://goodearthgraphics.com/showcave/menu.html.2016 Accessed 6 April 2016

http://nckms.org/wp-content/uploads/2018/05/2005 Jaspervisitation.pdf.2019 Accessed 28 March 2019

http://www.wrcc.dri.edu/cgi-bin/cliMAIN.pl?nv4514.2016 Accessed 12 December 2016

https://irma.nps.gov/Stats/.2017 Accessed 2 March 2017 https:/www.nps.gov/grba/learn/nature/algae-reduction.htm.2016 Accessed 12 December 2016

Jernigan JW (2001) A mathematical model of air temperature in Mammoth Cave, Kentucky. Journal of Cave and Karst Studies 63: 3-8

Jiménez-Sánchez M, Domínguez-Cuesta MJ, Aranburu A, Martos E (2011) Quantitative indexes based on geomorphic features: a tool for evaluating human impact on natural and cultural heritage in caves. J Cult Herit 12:270-278. https://doi.org/10.1016/j.culher. 2011.01.004

Kim SS, Kim M, Park J, Guo Y (2008) Cave tourism: tourists characteristics, motivation to visit, and the segmentation of their behaviour. Asia Pac J Tour Res 13:299-318. https://doi.org/10.1080/ 10941660802280448

Lario J, Soler V (2010) Microclimate monitoring of Pozalagua cave (Vizcaya, Spain): application to management and protection of show caves. J Cave Karst Stud 72:169-180. https://doi.org/10.4311/ jcks20091sc0093

Las Vegas Year-To-Date Executive Summary, (2017). http://www.lvcva. com/stats-and-facts/visitor-statistics/ (Accessed 18 December 2018)

Mattey DP, Fisher R, Atkinson TC, Latin J-P, Durell R, Ainsworth M, Lowry D, Fairchild IJ (2013) Methane in underground air in Gibraltar karst. Earth Planet Sci Lett 374:71-80. https://doi.org/10. 1016/j.epsl.2013.05.011

McKenzie D, Gedalof ZM, Peterson DL, Mote P (2004) Climate change, wildfire and conservation. Conserv Biol 18:890-902

Middaugh G (1977) Practical experiences with carrying capacity. In: Aley T, Rhodes D (eds) National cave management symposium proceedings, Mountain View, Arkansas, October 26-29, 1976. Speleobooks, Albuquerque, pp 6-8

Mulec J (2014) Human impact on underground cultural and natural heritage sites, biological parameters of monitoring and remediation actions for insensitive surfaces: case of Slovenian show caves. J Nat Conserv 22:132-141. https://doi.org/10.1016/j.jnc.2013.10.001

National Center for Health Statistics (2017) NCHS nutrition data fact sheet. https://www.cdc.gov/nchs/data/factsheets/factsheet_nutrition. pdf. Accessed 8 June 2018

National Park Service (2012) Natural features and ecosystems: National Park Service, U.S. Department of the Interior, http://www.nps.gov/ grba/naturescience/naturalfeaturesandecosystems.htm. Accessed 12 February 2017

Pavlovich K (2003) The evolution and transformation of tourism destination network: the Waitomo Caves, New Zealand. Tour Manag 24: 203-216

Pavlovich K (2014) A rhizomic approach to tourism destination evolution and transformation. Tour Manag 41:1-8. https://doi.org/10.1016/j. qdypi.2009.12.006

Pflitsch A, Wiles M, Horrocks R, Pasecki J, Ringeis J (2010) Dynamic climatological processes of barometric cave systems using the example of Jewel Cave and Wind Cave in South Dakota, USA. Acta Carsologica 39:449-462

Prudic DE, Sweetkind DS, Jackson TR, Dotson KE, Plume RW, Hatch CE, Halford KJ (2015) Evaluating connection of aquifers to springs and streams, eastern part of Great Basin national park and vicinity, Nevada. In: USGS Professional paper, vol 1819. USGS, Reston, Virginia. https://doi.org/10.3133/pp1819

Ravbar N, Šebela S (2015) The effectiveness of protection policies and legislative framework with special regard to karst landscapes: insights from Slovenia. Environ Sci Pol 51:106-116. https://doi.org/ 10.1016/j.envsci.2015.02.013

Reinemann SA, Patrick NA, Baker GM, Porinchu DF, Mark BG, Box JE (2011) Climate change in Great Basin National Park: lake sediment and sensor-based studies. Park Sci 28:78-82

Reinemann SA, Porinchu DF, MacDonald GM, Mark BG, DeGrand JQ (2014) A 2000-yr reconstruction of air temperature in the Great Basin of the United States with specific reference to the Medieval 
Climatic Anomaly. Quat Res 82:309-317. https://doi.org/10.1016/j. yqres.2014.06.002

Rindam M (2014) Cave tourism: the potential of Asar Cave as a natural tourism asset at Lenggong Valley, Perak. SHS Web of Conferences 12:01014-01019. https://doi.org/10.1051/shsconf/20141201014

Santos Lobo HA (2015) Tourist carrying capacity of Santana cave (PETAR-SP, Brazil): a new method based on a critical atmospheric parameter. Tour Manag Perspect 16:67-75. https://doi.org/10.1016/ j.tmp.2015.07.001

Santos Lobo HA, Trajano E, de Alcântara MM, Bichuette ME, Basso Scaleante JA, Furquim Scaleante OA, Rocha BN, Villela Laterza F (2013) Projection of tourism scenarios onto fragility maps: framework for determination of provisional tourist carrying capacity in a Brazilian show cave. Tour Manag 35:234-243. https://doi.org/10. 1016/j.tourman.2012.07.008

Schmidt J (1987) Lehman caves. Great Basin National History Association, Salt Lake City

Šebela S, Turk J (2011) Local characteristic of Postojna Cave climate, air temperature, and pressure monitoring. Theor Appl Climatol 105: 371-386. https://doi.org/10.1007/s00704-012-0644-8

Šebela S, Turk J (2014) Sustainable use of the Predjama Cave (Slovenia) and possible scenarios related to anticipated major increase in tourist numbers. Tour Manag Perspect 10:37-45. https://doi.org/10.1016/j. tmp.2014.01.002

Šebela S, Prelovšek M, Turk J (2013) Impact of peak period visits on the Postojna Cave (Slovenia) microclimate. Theor Appl Climatol 111: 51-64. https://doi.org/10.1007/s00704-012-0644-8

Šebela S, Turk J, Pipan T (2015) Cave micro-climate and tourism: towards 200 years (1819-2015) at Postojnska jama (Slovenia). Cave Karst Sci 42:78-85

Shear WA (2007) Cave millipeds of the United States. V. The genus Idagona Buckett \& Gardner (Chordeumatida, Conotylidae, Idagoninae). Zootaxa 1463:1-12 http://www.mapress.com/ zootaxa/2007f/zt01463p012.pdf. Accessed 15 Dec 2017

Shear WA, Taylor SJ, Wynne JJ, Krejca JK (2009) Cave millipeds of the United States. VIII. New genera and species of polydesmid millipeds from caves in the southwestern United States. Zootaxa 2151:47-65 http://www.mapress.com/zootaxa/list/2009/zt02151. html. Accessed 15 Dec 2017

Stark N (1969) Microecosystems in Lehman Cave, Nevada. NSS Bull 31: 73-81

Steponaitis E, Andrews A, McGree D, Quade J, Yu-Te H, Broecker WS, Shuman BN, Burns SJ, Cheng H (2015) Mid-Holocene drying of the U.S. Great Basin recorded in Nevada speleothems. Quat Sci Rev 127:174-185. https://doi.org/10.1016/j.quascirev.2015.04.011

Středa T, Středova H, Vysoudil M (2014) Cave rock surface temperature evaluation using non-contact measurement methods. Acta Carsologica 43:257-268

Tang G, Arnone JA (2013) Trends in surface air temperature and temperature extremes in the Greta Basin during the 20th century from ground-based observations. J Geophys Res-Atmos 118:35793589. https://doi.org/10.1002/jgrd.50360

Taylor SJ, Holsinger JR (2011) A new species of the subterranean amphipod crustacean genus Stygobromus (Crangonyctidae) from a cave in Nevada, USA. Subterranean Biology 8:39-47. https://doi. org/10.3897/subtbiol.8.1230

Thomas S (2008) https://www.nps.gov/grba/learn/nature/lint-removal. htm. Accessed 25 June 2017

van Beynen P, Townsend K (2005) A disturbance index for karst environments. Environ Manag 36:101-116. https://doi.org/10.1007/ s00267-004-0265-9

Veni G (1999) A geomorphological strategy for conducting environmental impact assessments in karst areas. Geomorphology 31:151-180

Vilkamaa P, Heikki H, Taylor S (2011) The genus Camptochaeta in Nearctic caves, with the description of C. prolix sp. n. (Diptera, Sciaridae). ZooKeys 135:69-75. https://doi.org/10.3897/zookeys. 135.1624

Walker J, Halliday D, Resnick R (2014) Fundamentals of physics. Wiley, New York

Weary DJ, Doctor DH (2014) Karst in the United States: a digital map compilation and database. U.S. Geological Survey open-file report 2014-1156. https://doi.org/10.3133/ofr20141156

Webster KD, Mirza A, Deli JM, Sauer PE, Schimmelmann A (2016) Consumption of atmospheric methane in a limestone cave in Indiana, USA. Chem Geol 443:1-9. https://doi.org/10.1016/j. chemgeo.2016.09.020

Wernicke B, Axen GJ, Snow JK (1988) Basin and range extensional tectonics at the latitude of Las Vegas, Nevada. Geol Soc Am Bull 100:1738-1757

Zeppelini D, Taylor SJ, Slay ME (2009) Cave Pygmarrhopalites Vargovitsch, (Collembola, Symphypleona, Arrhopalitidae) in United States. Zootaxa 2204:1-18 http://www.mapress.com/ zootaxa/2009/f/zt02204p018.pdf. Accessed 15 Dec 2017

Zhong L, Deng J, Song Z, Ding P (2011) Research on environmental impacts of tourism in China: progress and prospect. Tour Manag Perspect 92:2972-2983. https://doi.org/10.1016/j.jenvman.2011. 07.011 